\title{
A Porolepiform Rhipidistian from the Lower Devonian of the Canadian Arctic
}

\author{
Hans-Peter Schultze ${ }^{1}$ \\ With 5 figures and 2 appendices
}

\begin{abstract}
A holoptychiid fish is described from the Lower Devonian of Arctic Canada. The new form is distinct from other holoptychiids by the presence of a large supraorbital bone and a boomerang-shaped tabular. Nasogaluakus n. gen. is the oldest and most primitive holoptychiid based on a phylogenetic analysis of porolepiforms and their closest relatives. The sequence of the genera corresponds to their stratigraphic appearance.
\end{abstract}

Key words: Porolepiform rhipidistian, morphology, phylogenetic analysis, Lower Devonian, Arctic Canada.

\section{Zusammenfassung}

Ein Holoptychiide aus dem Unterdevon der kanadischen Arktis wird beschrieben. Er unterscheidet sich durch ein großes Supraorbitale und die Bumerang-Form des Tabulare von allen übrigen Holoptychiiden. Nasogaluakus n. gen. ist der älteste und primitivste Holoptychiide, was durch eine phylogenetische Analyse der Porolepiformes belegt wird. Die Abfolge der Gattungen in diesem Verwandtschaftsschema stimmt mit ihrem zeitlichen Auftreten überein.

Schlïsselworte: Porolepiformer Rhipidistier, Morphologie, phylogenetische Analyse, Unterdevon, kanadische Arktis.

\section{Introduction}

In 1995, H.-P. Schultze and M. Otto, Museum für Naturkunde, Berlin, Germany, and S. Cumbaa and R. Day, Canadian Museum of Nature, Ottawa, Canada, rediscovered the locality of $M e$ lanognathus canadensis Jarvik, 1967, Dialipina salgueiroensis Schultze, 1968, and Heimenia sp. Ørvig, 1969 in the Bear Rock Formation, Lower Devonian, along the Anderson River of the western Canadian Arctic, about $330 \mathrm{~km}$ east of Inuvik. The locality was discovered by prospecting oil geologists for the Standard Oil Company in 1958. On this original material, which was deposited in the Canadian Museum of Nature, the descriptions by Jarvik (1967), Schultze (1968) and Ørvig (1969) were based. In 1997, H.-P. Schultze and O. Hampe, Museum für Naturkunde, Berlin, Germany, and S. Cumbaa and R. Day, Canadian Museum of Nature, Ottawa, Canada, J. Chorn, Natural History Museum, Lawrence, Kansas, and J. Harrison, Tuscon, Arizona, extensively excavated the locality and recovered many complete specimens of the actinopterygian Dialipina sal- gueiroensis (Schultze \& Cumbaa in press) and of an undescribed acanthodian, many isolated cosmine covered bones of a porolepiform, few remains of the dipnoan Melanognathus, and a single specimen of a porolepiform with cosmine free bones which will be described here. The fish fauna from the Anderson River includes teleostome fishes only. Agnathans, thelodonts, placoderms or chondrichthyans were not discovered, not even in acid residues. The invertebrate fauna is represented by poorly preserved inarticulate brachiopods ('Lingula'), ostracods, gastropods and better preserved eurypterids (Braddy \& Dunlop in press). Few plant remains occur. The Canadian Geological Survey cited the Bear Rock Formation as "Fauna virtually nonexistent, some ostracods (Moelleritia canadensis), brachiopods and colonial corals" (Morrow \& Hills 1990: 43), which seems to be true for most of the formation. The fish fossils are restricted to two $150 \mathrm{~m}$ long lenses, which cross the river at a distance of about $1 \mathrm{~km}$, at the base of the formation. In addition, a local occurrence was discovered in 1975 , about $7 \mathrm{~km}$ down the river.

\footnotetext{
${ }^{1}$ Institut für Paläontologie, Museum für Naturkunde, Humboldt Universität, Invalidenstr. 43, D-10115 Berlin, Germany. Received April 2000, accepted May 2000
} 


\section{Systematic Paleontology}

Class Osteichthyes Huxley, 1880

Subclass Sarcopterygii Romer. 1955

Infraclass Rhipidistia Cope. 1889

Order Porolepiformes Jarvik. 1942

Family Holoptychiidae Owen. 1860

Genus Nasogaluakus n. gen.

Diagnosis: A holoptychiid with a combination of two primitive porolepiform features (anterior margin of parietals behind orbits. parietal does not contact supraorbital) not present in other holoptychiids and two known holoptychiid features (anterior position of posterior pit line on postparietal and loss of cosmine); boomerang-shaped tabular which is anteriorly twice as wide as posteriorly, one large supraorbital and one large subsquamosal.

Derivatio nominis: Named after the late helicopter pilot David Nasogaluak, an Inuvaluit from Tuktoyaktuk, NorthWest Territories, Canada, who caught for us three $80 \mathrm{~cm}$ long inconnus (Stenodus leucichthys) in the Anderson River. while we were searching for additional localities of fossil fish.

Type species: Nasogaluakus chorni $\mathrm{n}$. sp.

Time: Early Devonian.

\section{Nasogaluakus chorni n. sp.}

Figs 1-4

Diagnosis: Same as for the genus.

Holotype and only specimen: Flattened and somewhat disarticulated skull CMN 51129 (Canadian Museum of Nature. Ottawa. Ontario. Canada) (Figs 1-3).

Type locality: Standard Oil Co. locality no. AR.25.58 (Mr. Ben Moore's Anderson River traverse in summer 1958), $68^{\circ} 11^{\prime} 06^{\prime \prime} \mathrm{N} /$ $125^{\circ} 49^{\prime} 72^{\prime \prime} \mathrm{W}$. Anderson River. about $330 \mathrm{~km}$ east of Inuvik and $150 \mathrm{~km}$ southsouthwest of Paulatuk, Northwest Territories. Canada.

Type horizon and age: Lower part of the Bear Rock Formation. Emsian, Lower Devonian (indicated by occurrence of Moellerita, a large ostracode. identified by A. Abushik and I. Evdokimova, All-Russian Geological Institute. St. Petersburg).
Derivatio nominis: Named after Dr. John Chorn, The University of Kansas, Lawrence, Kansas, U.S.A., the finder of the specimen.

Description: A dorsally flattened skull (Figs $1,2)$ is preserved. The bones are delicately ornamented with rounded tubercles; cosmine is not developed. The lateral line canals open by many pores at the bone surface. Postparietals and left tabular form one block; the anterior skull roof is disarticulated. Small bones (tesserae) fill the space between the left postparietal and the left squamosal. The right subsquamosal touches the anterolateral corner of the postparietals. In front of the subsquamosal, the anterior part of the skull roof follows. The jugals lie laterally to skull roof bones; the right jugal is visible in internal view. The preserved right maxilla (Fig. 3 ) is displaced anterolaterally.

The postparietals (Fig. 2) are the largest bones of the skull roof. They are widest at the anterior tip of the tabular and become $60 \%$ narrower towards the anterior margin. The anterior margin of the postparietal is straight, it runs obliquely from the anteriormost median point to a more posterior lateral edge with an indentation close to the lateral edge (also in Holoptychius, Jarvik 1972: fig. 37B, pl. 24, fig. 3, pl. 29, fig. 2). The lateral margin runs posterolaterally to the anteromedial corner of the tabular; it corresponds to the overlap area for the right prespiracular plate. It follows an embayment for the tabular. Two short pit lines appear in the middle of the postparietals at the level of the anterior tip of the tabular. The posterior part of the postparietals is not preserved except for the right margin. This shows that the postparietals reach not far behind the posterior end of the tabular.

The tabular is boomerang-shaped; its anterior margin is twice as wide as the posterior one. One short. straight pit line is situated medial to the middle point of the arched lateral margin. The lateral margin is embayed for the attachment of the extratemporal.

The anterior skull roof (Fig. 2) is only partly preserved and partly covered by cheek bones. The posterior part of the right parietal is missing. It is laterally covert by a bone. Few lateral line pores open on the surface, and the lateralmost part of the anterior pit line is visible. The lateral part of the right parietal is covered by the

Fig. 1. Nasogahakus chorni n. gen. and n. sp.. Emsian. Lower Devonian. Anderson River, Arctic Canada. Holotype CMN 51129. disarticulated skull. Scale $=1 \mathrm{~cm}$ 


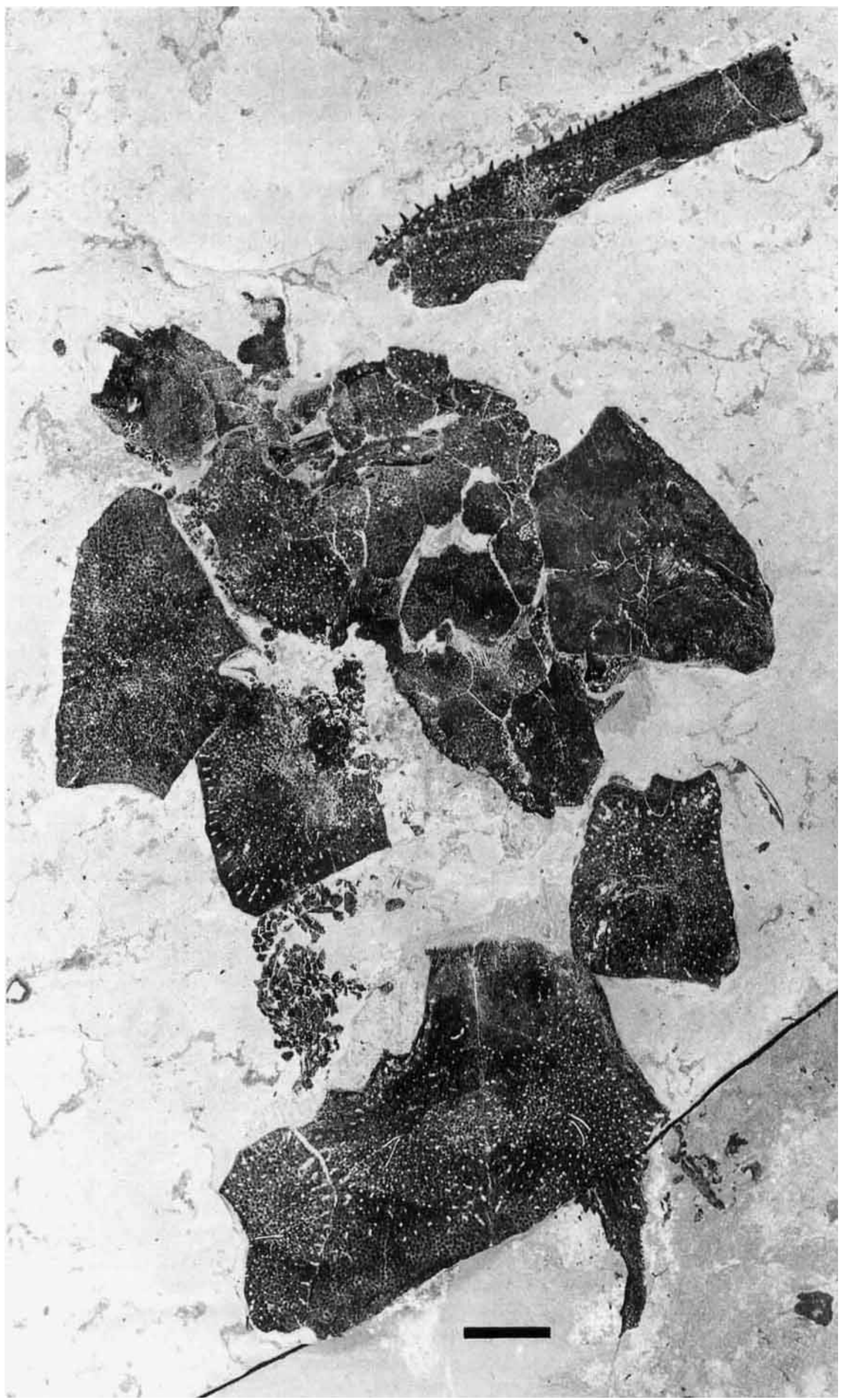


left bone anterolateral to the parietal. A short anterior piece of the left parietal is preserved. A small hexagonal median bone (pineal plate?) fits into the space between the anteromedial margins of the parietals. It follows anteriad a larger median bone which borders the two anterior margins of the hexagonal median bone, posterolaterally the bones anterolateral to the parietals, and laterally and anteriorly other small bones. Except for the two median bones and one bone in the following series, all other bones show pores of the lateral line system. The bone anterolateral to the right parietal is covered by its left counterpart; its anterior and most lateral parts are visible. The anterior part extends with very extensive overlap areas for the anterior following bones. These overlap areas are seen isolated anterolateral to the left parietal. Two series of small bones lie anterior to the larger median bone. A large supraorbital forms the most lateral bone of the first series. It has contact with the bone anterolateral to the parietal. with the first and second series of small bones anterior to the median bones, and in addition with not preserved anterior bones and the lacrimal. The internal surface of a thick bone, possibly the left vomer, is visible in front of the supraorbital. The concave margin towards the supraorbital is the margin to the internasal cavity. if the interpretation as vomer is correct.

Small tesserae lie between jugal, supraorbital. and ?vomer. These could be oral dental plates as described by Jarvik (1963, 1972), nevertheless the surface structure corresponds very well with that of other skull bones. There is only one small plate with three pointed teeth in front of the anterior series of small bones. This small plate is clearly a dental plate. Vertically standing bones appear between the series of small bones. The largest one with an opening of a lateral line canal seems to be the left premaxilla.

The left squamosal and right (in internal view) and left jugals (Fig. 2) are preserved. The squamosal appears as a pentagonal bone. Its contact with the preoperculum is straight and long: in contrast, its posteroventral margin with the quadratojugal is very short. The long ventral margin indicates the presence of large or numerous submandibulars. The squamosal connects obliquely with the jugal. The anterior margin and the anterior part of the dorsal margin of the squamosal are disintegrating into tesserae. This feature is visible in many bones. Such a tessera has fallen out at the dorsal tip of the jugal, and the borders are marked in the subsquamosal.
The feature is best seen on the inside of the thick bone anterior to the supraorbital. The median part of the thick bone shows many sutures, a first indication of the division into tesserae. A field of tesserae with external features like dermal bones lies between the left postparietal and the left squamosal.

Left and right jugals are preserved, the right one presents its internal surface. The posterior margin is concave; here the subsquamosals suture. The ventral margin is straight and inclined in its anterior part where it contacts with both the anterior part of the maxilla and with the posterior margin of the lacrimal. The anterior tip of the jugal is abruptly ending, forming a short section of the posterior margin of the orbit. The anterodorsal margin for the postorbital and the posterodorsal margin for the squamosal are inclined at about the same angle $\left(35^{\circ}\right)$. The course of the infraorbital and the jugal sensory canals can clearly be followed by deep depressions on the bone surface and elevations on the inner side of the bone.

A nearly rectangular bone, here interpreted as subsquamosal, touches the anterolateral corner of the right postparietal (Fig. 2). The dorsal and ventral margins of the subsquamosal run towards each other so that the anterior depth is $70 \%$ of the posterior depth of the bone. The posterior margin is straight. The anterior margin shows two embayments, the upper one may represent a fallen out tessera. The sutures of one tessera appear just below the upper invagination. The anterior margin of the subsquamosal corresponds to the posterior margin of the jugal.

The right maxilla (Fig. 3) lies lateral to the skull roof. Two thirds of the bone are preserved in substance, the posterior third only as impression. The bone has the same depth from the posterior end of the lacrimal until short before its end. It gets shallower at the anterior end below the lacrimal. The anterior part below the lacrimal diminuishes its depth towards a tip below the anterior end of the lacrimal. The teeth have the vertical striations typical for folded teeth. The enlargement of the broken region of the anteriormost part of the maxilla shows that there is more than one tooth row. The maxilla carries openings of the infraorbital canal.

The lacrimal is attached to the anterior part of the maxilla. It borders the jugal with an oblique margin. The dorsal margin forms the ventral border of the orbit and of the supraorbital anteriorly. The anterior margin shows a notch for the posterior external nasal opening and for the infraorbital canal. 


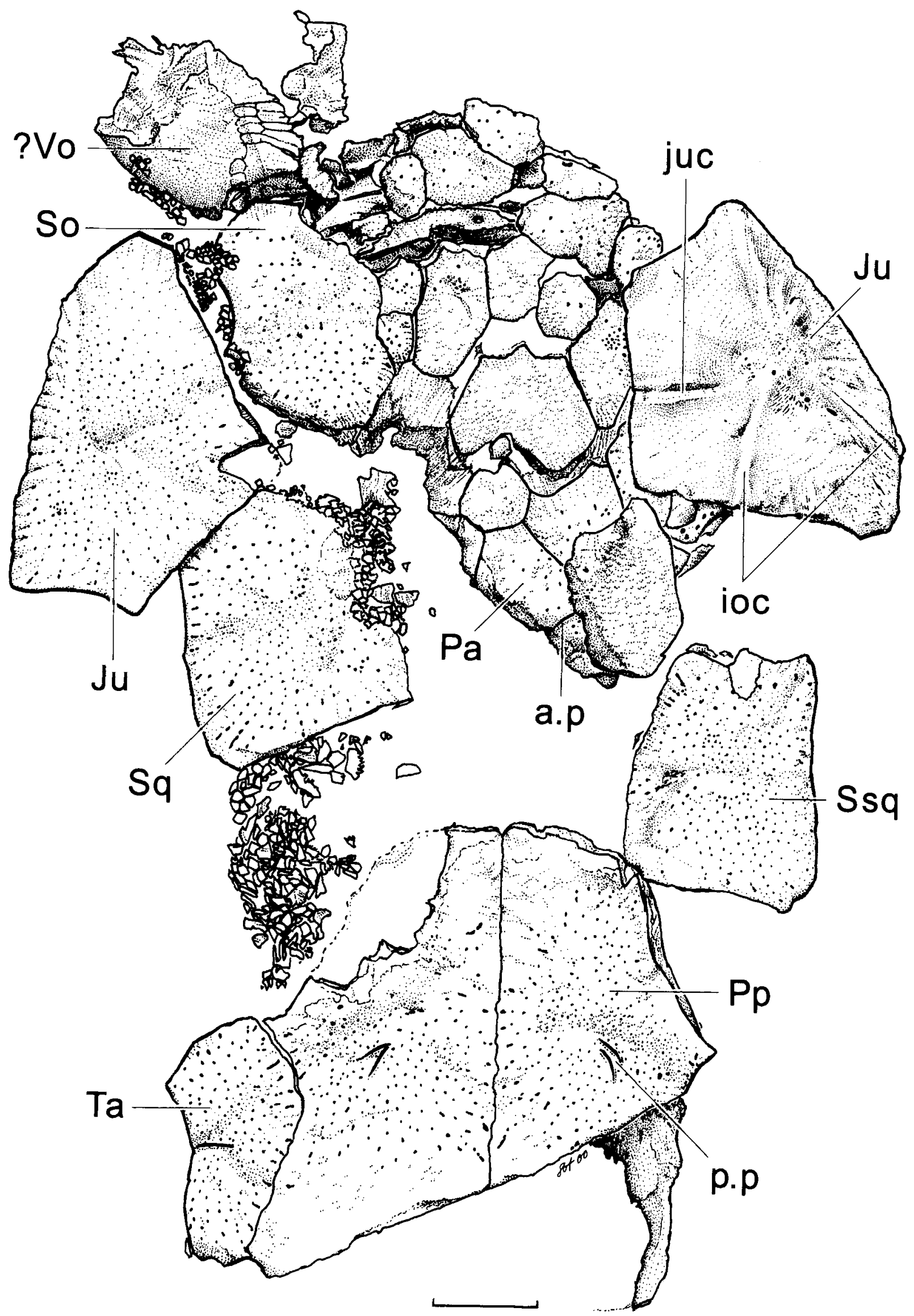

Fig. 2. Nasogaluakus chorni n. gen. and n. sp., Emsian, Lower Devonian, Anderson River, Arctic Canada. Holotype CMN 51129 , disarticulated skull. Scale $=1 \mathrm{~cm}$.

a.p. anterior pit line; ioc, infraorbital sensory canal; juc, jugal sensory canal; Ju, jugal; Pa, parietal; Pp, postparietal; p.p. posterior pitline; So, supraorbital; Sq, squamosal; Ta, tabular; ?Vo, questionable left vomer 


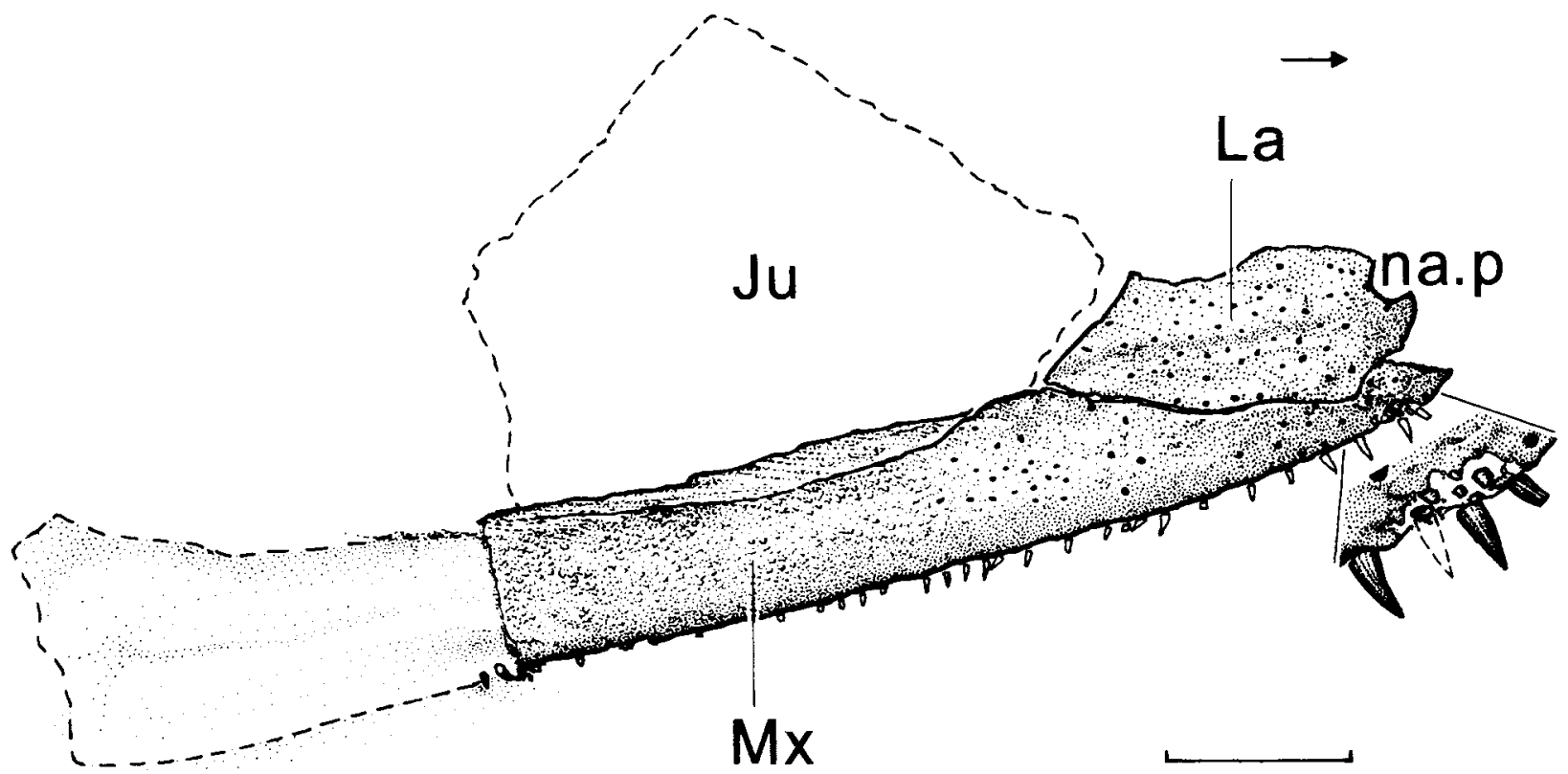

Fig. 3. Nasogaluakus chorni n. gen. and n. sp., Emsian. Lower Devonian. Anderson River, Arctic Canada. Holotype CMN 51129, right maxilla with enlarged anterior part with teeth and lacrimal. Photograph taken from specimen under alcohol. Arrow points anteriorly. Scale $=1 \mathrm{~cm}$.

Ju, jugal: La. lacrimal: Mx. maxilla: na.p. posterior nasal opening

The reconstruction (Fig. 4) of skull roof and cheek is difficult because of missing bones. Anterior and posterior skull roof are placed together on the base of a relationship between parietal and postparietal of 40 to $50 \%$ in holoptychiids. The anterior small bones contact each other very well. so that the skull roof is reconstructable to the premaxillae. Maxilla, lacrimal, and jugal fit closely to- gether. Supraorbital, lacrimal, and jugal form three quarters of the orbital margin. The last quarter is formed by the postorbital which is reconstructed as a large bone between jugal, supraorbital. parietal, prespiracular, and squamosal; an anteroventral process of the postorbital reaches the orbit. The squamosal would touch the tabular in the presented restoration. An elongated pre-

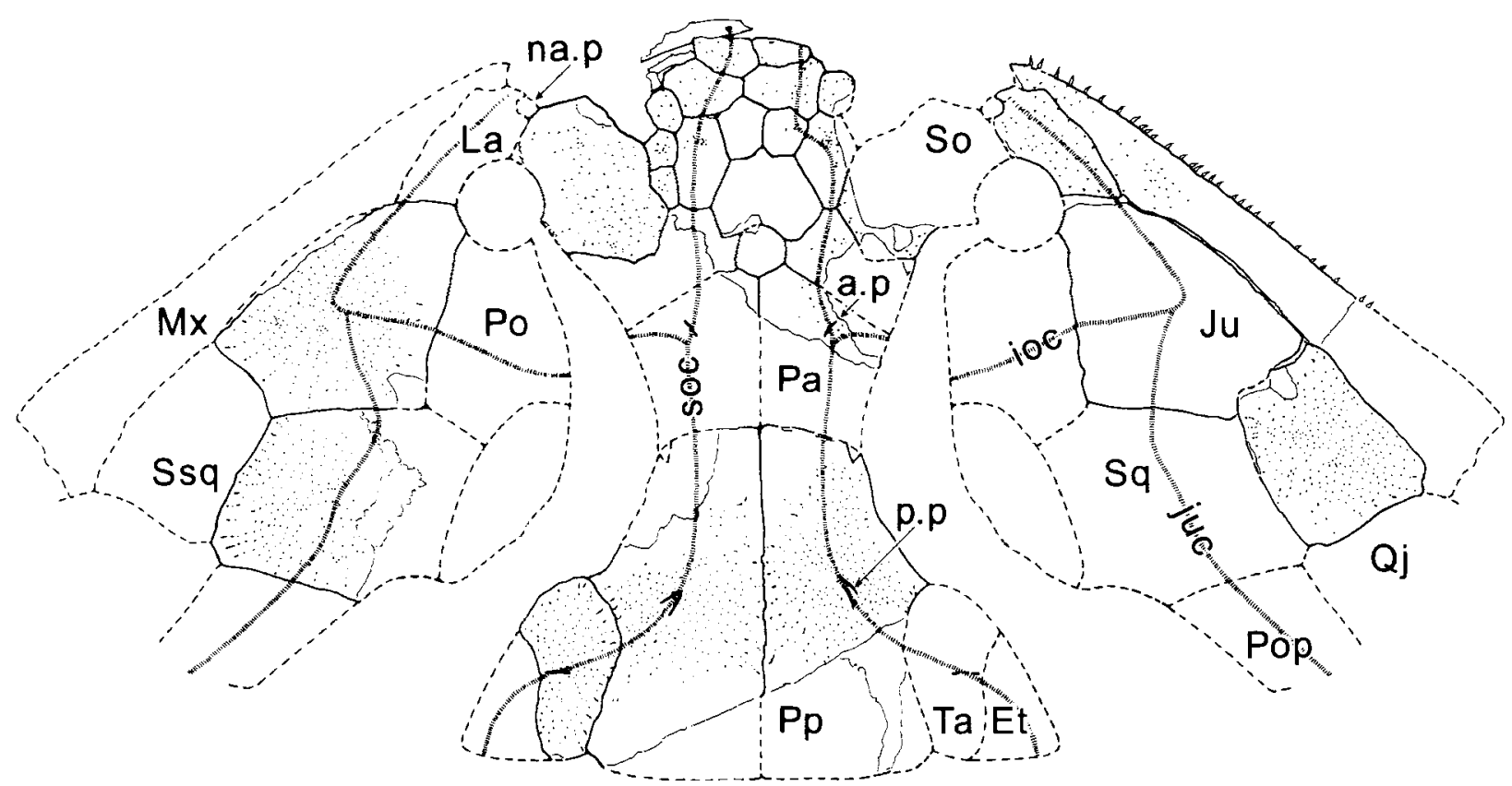

Fig. 4. Reconstruction of the dorsal and lateral side of the skull of Nasogaluakus chomi n. gen. and n. sp. a.p. anterior pit line: Et. extratemporal: ioc. infraorbital sensory canal: juc, jugal sensory canal; Ju, jugal; La, lacrimal; Mx, maxilla: na.p. posterior nasal opening: Pa, parietal: Po. postorbital: Pop. preoperculum: Pp. postparietal; p.p. posterior pit line: Qj. quadratojugal; So, supraorbital: soc. supraorbital sensory canal: Sq. squamosal: Ssq, subsquamosal; Ta, tabular 
spiracular lies dorsal of both, postorbital and squamosal. The placement of jugal and squamosal leaves a large place for the subsquamosal, present on the right side. The reconstruction of both preoperculum and quadratojugal is hypothetical.

The course of the lateral line system is assumed except on the jugal. The pores of the lateral line system are widely distributed so that one cannot use their appearance to reconstruct the lateral line canals with confidence. The otic sensory canal should pass through the growth centres of postparietal and parietal. Infraorbital and supraorbital sensory canals branch off in the parietal. The supraorbital sensory canal passes through the bone anterolateral to the parietal and through small bones lateral to the three median bones without pores of the lateral line system. The infraorbital sensory canal runs in the jugal where it turns anteriorly in an acute angle of $70^{\circ}$. It passes through the lower part of the lacrimal. The jugal sensory canal branches off vertically from the infraorbital sensory canal in the growth centre of the jugal. The course of the canal through the squamosal is not marked by a groove on the surface of the bone.

\section{Comparison}

A phylogenetic analysis of Devonian porolepiforms was performed to place Nasogaluakus n. gen. within the group. I excluded the porolepi- forms Duffichthys (Ahlberg 1992: parts of lower jaw), Hamodus (Obrutschew 1933: teeth), Heimenia (Ørvig 1969: scales), Paraglyptolepis (Vorobyeva 1987: ethmosphenoid), and Ventalepis (Schultze 1980: scales) from the analysis because of insufficient information. Heimenia ensis from the Lower Devonian of West Spitsbergen is under study by Gaël Clement in Paris. Ørvig (1969) attributed porolepiform scales from Anderson River to Heimenia sp. Many isolated bones of a porolepiform, which may belong to Heimenia sp., are now available from the Lower Devonian of Anderson River; the material has not been studied yet. Nevertheless, it is clear that the here described specimen is different from the porolepid with cosmine-covered bones and scales from Anderson River which might belong to Heimenia.

For the cladistic analysis (with PAUP 3.1.1), I used those characters of Zhu \& Schultze (in press), which are characteristic of porolepiforms, and in addition those, which are different within the porolepiforms (Appendices 1 and 2). All characters were treated unordered; and the delayed option (DELTRAN) was used. Psarolepis was placed into the outgroup. The consensus tree (Fig. 5) of four most parsimonious trees resulted in the following arrangement: Psarolepis, Youngolepis (Powichthys (Porolepis (Nasogaluakus (Quebecius, Glyptolepis, Holoptychius, Laccognathus)))). The statistics for the consensus tree are: $\mathrm{CI}=0.837$, CI excluding uninformative characters $=0.773 ; \mathrm{RI}=0.814$; tree length $=80$.

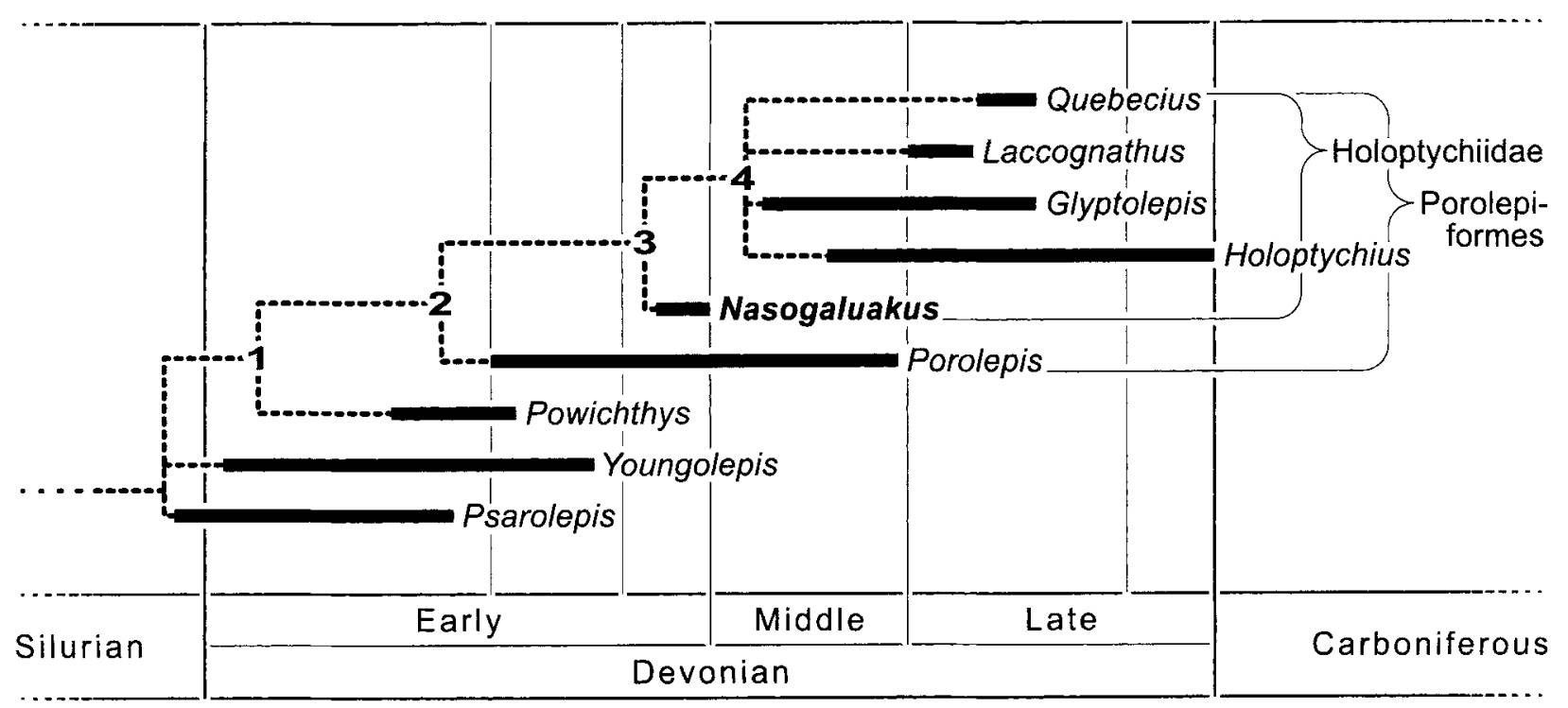

Fig. 5. Hypothesis of interrelationship of porolepiform rhipidistians and time range of porolepiform taxa. Consensus tree of four most parsimonious trees; outgroup = Psarolepis; all characters unordered; $\mathrm{CI}=0.837, \mathrm{CI}$ excluding uninformative characters $=0.773 ; \mathrm{RI}=0.812 ;$ tree length $=80$. Unique characters (DELTRAN) at nodes are: Node 1: 15(0), 19(1), 21(1). 25(1). 26(1), 47(1), and 49(1). Node 2: 5(1) (also Youngolepis), 7(1),8(1), 9(1), 10(1) (also Psarolepis), 17(1) (reversal Quebecius). $23(1), 27(0), 29(0)$ (reversal Quebecius), 30(1), 32(0-2), 37(1), 41(1), 42(0), 44(1), 46(1-2), 48(1), 50(1), 58(0), 60(1), and 61(0). Node 3: 20(1), and 57(0). Node 4: 4(0), 6(1), 31(1) (also Psarolepis), 34(1), 35(1), 56(1), and 59(0) 
Powichthys and all porolepiforms (Node 1) have in common the presence of subsquamosals, a preoperculosubmandibular, many openings in the postnasal wall and a basicranial fenestra with arcual plates. A single subsquamosal is present in Nasogaluakus. The unique characters 15(0), 19(1) and 21(1) at Node 1 occur also outside the porolepiforms in other rhipidistians, which are not included in the analysis.

The Porolepiformes (Node 2) are characterized by many unique characters in this analysis. Here, only those characters, which also occur in Nasogaluakus n. gen., are mentionned: absence of intertemporal $[7(1)]$ and supratemporal [8(1)], a contact between postparietal and cheek [9(1)]. a dermal joint between parietal and postparietal $[10(1)]$, and a course of the otic canal through the growth centre of the postparietal [17(1)]. These characters justify a placement of Nasogaluakus n. gen. within the Porolepiformes.

Porolepis is the only genus of the Porolepididae included in the analysis. in contrast to four genera (Quebecius, Glyptolepis, Holoptychius, Laccognathus) of the Holoptychiidae. Nasogaluakus n. gen. and all holoptychiids are more advanced than Porolepis (Node 3) by the anterior position of the posterior pit line on the postparietal [20(1)] and the loss of cosmine [57(1)]. The anterior margin of the parietals lies behind the orbits [4(1)] and the parietal does not contact the supraorbital [6(0)] in Nasogaluakus n. gen. like in Porolepis and Powichthys. All other holoptychiid characters are not known for Nasogaluakus n. gen., even though some (e.g.. round scales) may be present. Nasogaluakus n. gen. appears as the most primitive holoptychiid.

The tabular is anteriorly wider than at its posterior margin in holoptychiids (Laccognathus, Vorobyeva 1980: figs 4, 5; Glyptolepis, Jarvik 1972: figs 38, 42, pl. 15: Holoptychius, Jarvik 1972: fig. 45A, pl.29, fig. 2) except in Quebecius (Cloutier \& Schultze 1996: fig. 15) and in contrast to Porolepis (Jarvik 1972: fig. 43A) which has a wider posterior margin. The jugal is short and deep [character 22(0)] as in other holoptychiids (Laccognathus, Vorobyeva 1980: fig. 4: Glyptolepis, Jarvik 1972: fig. 44, pl. 16, figs 1. 2: Holoptychius, Jarvik 1972: fig. 45C. pl. 24. fig. 4: Quebecius, Cloutier \& Schultze 1996: fig. 15) and in contrast to the elongated jugal of Porolepis (Jarvik 1972: fig. 43C). Nasogaluakus n. gen. resembles holoptychiids in all these characters: it is distinct in details. The boomerang shaped tabular which is anteriorly twice as wide as posteriorly, and a single large subsquamosal are unique to
Nasogaluakus $\mathbf{n}$. gen. The lacrimal forms the ventral margin of the orbit in all porolepiforms; there are differences in the size of the part anterior to the orbit which do not distinguish clearly Porolepis from holoptychiids. A large supraorbital, similar to that in Nasogaluakus n. gen., has been figured in one specimen (Sedgwick Museum, Cambridge: SMC J554) of Porolepis sp. by Ahlberg (1991: fig. 5); such a large supraorbital is otherwise unknown within the Porolepiformes.

The phylogenetic relationships of the taxa match their stratigraphic occurrence (Fig. 5). Psarolepis already occurs in the Late Silurian (Zhu \& Schultze 1997) and reaches into the Pragian, and Youngolepis and Powichthys in the earliest Devonian (Lochkovian) and into the Pragian. Porolepis is known from the middle Early Devonian (Pragian) until close to the end of the Middle Devonian (Givetian). Nasogaluakus n. gen., being a basal holoptychiid, already appears in the latest Early Devonian (Emsian), whereas all other holoptychiids except for few isolated remains are Middle and Late Devonian forms with a maximal abundance in the Frasnian. Isolated holoptychiid remains of about the same age have been described from the Emsian of Overath, WGermany (Gross 1933: 69, one scale) and from Emsian (age after Hamdi \& Janvier 1981) of the Eastern Alborz (Blieck et al. 1980: 149 and pl. I, fig. 17. scales and one cleithrum).

\section{Conclusions}

The disarticulated skull of Nasogaluakus chorni $\mathrm{n}$. gen. and n. sp. is the only holoptychiid porolepiform. which was discovered within many cosmine covered porolepiform bones in the Lower Devonian at Anderson River, Arctic Canada. It represents the most primitive and the oldest holoptychiid porolepiform based on a phylogenetic analysis of porolepiforms and their closest relatives.

Nasogaluakus n. gen. has two characters (posterior pit line on anterior half of postparietal and a short and deep jugal) in common with holoptychiids with certainty; whereas the status of four holoptychiid characters is unknown (direction of the axis of parasymphysial tooth whorl, absence of median gular, presence of palatal opening, round scales). Nasogaluakus n. gen. has two porolepid characters (posterior position of the anterior margin of parietal and lack of parietalsuborbital contact) which put the genus at the base of the holoptychiids. 


\section{Acknowledgements}

I thank the German Science Foundation (DFG grants Schu $212 / 10-1+2$ to H.-P. Schultze), National Geographic Society (grant 5742-96 to H.-P. Schultze), and the Canadian Museum of Nature (Research Advisory Committee grants to S. Cumbaa) for the support of the field work. I acknowledge specifically the great help of Les Kutny, Science Institute of the Northwest Territories, Inuvik (now the Aurora Research Institute), and that of Richard Day, Canadian Museum of Nature, Ottawa, Drs. O. Hampe, Museum für Naturkunde, Berlin, J. Chorn, Lawrence, Kansas, and J. Harrison, Tucson, Arizona, during the field work. The Aurora Research Institute, Inuvik, and the Polar Continental Shelf Project, Natural Resources, Canada, provided important logistical support. The specimen was prepared with acetic acid by Mrs. B. Michel (supported by DFG) and with needles by Mr. L. Berner; the photographs were done by Mrs W. Harre and the drawings by Mrs E. Siebert, all from the Museum fur Naturkunde in Berlin. I thank Mrs A. Abushik and Mrs I. Evdokimova, both of The All-Russian Geological Research Institute. St. Petersburg, for the identification of the ostracodes. I greatly appreciate the review of the manuscript by P. Ahlberg, London, P. Janvier, Paris, and M. Otto, Berlin.

\section{References}

Ahlberg, P. E. 1991. A re-examination of sarcopterygian interrelationships, with special reference to the Porolepiformes. - Zoological Journal of the Linnean Society 103: 241-287.

- 1992. A new holoptychiid porolepiform fish from the Upper Frasnian of Elgin, Scotland. - Palaeontology 35 (4): $813-828$.

Blieck, A., Golshani, F., Goujet, D., Hamdi, A., Janvier, P., Mark-Kurik, E. \& Martin, M. 1980. A new vertebrate locality in the Eifelian of the Khush-Yeilagh Formation, Eastern Alborz, Iran. - Palaeovertebrata 9: 133-154.

Braddy, S. J. \& Dunlop, J. A. In press. Early Devonian eurypterids from the Northwest Territories of Arctic Canada. - Canadian Journal of Earth Science.

Cloutier, R. \& Schultze, H.-P. 1996. Porolepiform fishes (Sarcopterygii). In Schultze, H.-P. \& Cloutier, R. (eds). Devonian Fishes and Plants of Miguasha, Quebec, Canada: 248-270, Verlag Dr. Friedrich Pfeil, München.

Cope, E. D. 1887. Zittel's Manual of Palacontology. - American Naturalist 21: 1014-1019.

Gross, W. 1933. Die unterdevonischen Fische und Gigantostraken von Overath. - Abhandlungen der Preußischen Geologischen Landesanstalt, Neue Folge 145: 41-70.

- 1942. Über den Unterkiefer einiger devonischer Crossopterygier. - Abhandlungen der Preußischen Akademie der Wissenschaften, mathematisch-naturwissenschaftliche Klasse 7: 1-51.

Hamdi, B. A. \& Janvier, P. 1981. Some conodonts and fish remains from the Lower Devonian (lower part of the Kushyeylaq Formation), northeast Shahrud. - Geological Survey of Iran Reports 49: 195-212.

Huxley, T. H. 1880. On the application of the laws of evolutuion to the arrangement of the Vertebrata, and more particular of the Mammalia. - Proceedings of the Zoological Society of London 1880: 649-661.
Jarvik, E. 1942. On the structure of the snout of crossopterygians and lower gnathostomes in general . - Zoologiska Bidrag från Uppsala 21: 235-675.

- 1963. The composition of the intermandibular division of the head in fish and tetrapods and the diphyletic origin of the tetrapod tongue. - Kungliga svenska Vetenskaps Akademiens Handlingar (4) 9: 1-74.

- 1967. On the structure of the lower jaw in dipnoans: with a description of an early Devonian dipnoan from Canada. Melanognathus canadensis gen. et sp. nov. - Journal of the Linnean Society, Zoology 47: 155-183.

- 1972. Middle and Upper Devonian Porolepiformes from East Greenland with special reference to Glyptolepis groenlandica n. sp. and a discussion on the structure of the head in the Porolepiformes. - Meddelelser om Grønland 187: $1-295$.

- 1980. Basic Structure and Evolution of Vertebrates. Volume 1: XVI + 575 pp., Academic Press, New York.

Morrow, D. W. \& Hills, L. V. 1990. Bear Rock Formation. In Glass, D. J. (ed.). Lexicon of Canadian Stratigraphy, Volume 4, Western Canada, Including Eastern British Columbia, Alberta, Saskatchewan and Southern Manitoba: 43. Canadian Society of Petroleum Geologists, Calgary. Alberta.

Obrutschew, D. W. 1933. [Description of four new species from the Devonian of Leningrad Province.] - Materials of ther Central Scientific Geological and Prospecting Institute, Palaeontology and Stratigraphy Magazine 1: 12-14 [In Russian].

Ørvig, T. 1969. Vertebrates from the Wood Bay Group and the position of the Emsian-Eifelian boundary in the Devonian of Vestspitsbergen. - Lethaia 2: 273-328.

Owen, R. 1860. Palaeontology; or, a systematic summary of extinct animals and their geological remains. $\mathrm{XV}+$ 420 pp., Adam and Charles Black, Edinburgh.

Romer, A. S. 1955. Herpetichthyes, Amphibioidei. Choanichthys or Sarcopterygii? - Nature 176: 126-127.

Schultze, H.-P. 1968. Palaeoniscoidea-Schuppen aus dem Unterdevon Australiens und Kanadas und aus dem Mitteldevon Spitzbergens. - Bulletin of the British Museum (Natural History) Geology 16: 341-368.

- 1980. Crossopterygier-Schuppen aus dem obersten Oberdevon Lettlands (Osteichthyes, Pisces). - Neues Jahrbuch für Geologie und Paläontologie, Monatshefte, Jahrgang 1980: $215-228$.

Schultze, H.-P. \& Cumbaa, S. In press. Dialipina and the characters of basal actinopterygians. In P. Ahlberg (ed.). Major Events in Early Vertebrate Evolution: Palaeontology, Phylogeny and Development: Taylor \& Francis, London.

Vorobyeva, E. I. 1980. Observations on two rhipidistian fishes from the Upper Devonian of Lode, Latvia. - Zoological Journal of the Linnean Society 70: 191-201.

- 1987. [Porolepid crossopterygian from the Middle Devonian of Estonia.] - Paleontologicheskii Zhurnal 1987 (1): 76--85 [In Russian].

Zhu Min \& Schultze, H.-P. 1997. The oldest sarcopterygian fish. - Lethaia 30: 293-304.

Zhu Min \& Schultze, H.-P. In press. Interrelationships of basal osteichthyans. In Ahlberg, P. (ed.). Major Events in Early Vertebrate Evolution: Palaeontology, Phylogeny and Development: Taylor \& Francis, London. 


\section{Appendix 1}

List of characters selected from Zhu \& Schultze (in press. numbers in [..])

1. [11] Postrostral: postrostral mosaic of small variable bones (0): large median postrostral, with or without accessory bones (1).

2. [16] Number of tectals: one (0): two or more (1).

3. [18] Number of supraorbitals: one (0): two (1): more than two (2).

4. [20] Anterior margin of parietals: between or in front of orbits (0): slightly posterior to orbits (1).

5. [21] Pineal opening: open (0): closed (1).

6. [23] Parietal-supraorbital contact: absent $(0)$ : present (1).

7. [25] Intertemporal: present (0): absent (1).

8. [26] Supratemporal: present (0): absent (1).

9. [30] Postparietal and cheek contact: absent (0): present (1).

10. [31] Dermal joint between parietal and postparietal: absent (0): present (1).

11. [37] Processus dermintermedius: absent (0): present (1).

12. [39] Position of posterior naris: extemal. far from jaw margin (0): external, close to jaw margin (1).

13. [42] Ethmoid commissure: present (0): absent (1).

14. [43] Course of ethmoid commissure: middle portion through median rostral (0); sutural course (1); through bone centre (2).

15. [45] Supraorbital and infraorbital sensory canals: in contact rostrally (0): not in contact rostrally (1).

16. [46] Relationship of infraorbital sensory canal to premaxilla: infraorbital canal entering premaxilla (0); infraorbital canal following dorsal margin of premaxilla (1).

17. [47] Course of otic sensory canal: not through growth centre of postparietal (0): through growth centre of postparietal (1).

18. [48] Posterior end of supraorbital sensory canal: in postparietal (0): in parietal (1): in intertemporal (2).

19. [49] Otic and supraorbital sensory canals: not in contact (0): in contact (1).

20. [51] Position of posterior pit line: on posterior half of postparjetal (0): on anterior half of postparietal (1).

21. [55] Posteriorly deep maxilla: present (0): absent (1).

22. [57] Shape of jugal: short and deep (0): long and low (1).

23. [59] Prespiracular: absent (0): present (1).

24. [62] Squamosal. quadratojugal and preopercular bones: separated $(0)$ : fused (1).

25. [64] Subsquamosals: absent (0): present (1).

26. [69] Preoperculosubmandibular: absent (0): present (1).

27. [70] Foramina on dermal cheek bones: absent (0): present (1).

28. [71] Vertical bar-like preopercular bone: absent $(0)$ : present (1).

29. [73] Postorbital: restricted to anterior cranial division (0): spanning two divisions (1).

30. [80] Anterior end of dentary: not modified $(0)$ : modified into support for parasymphysial tooth whorl (1).

31. [82] Axis of parasymphysial tooth whorl: parallel to dentary (0): perpendicular to dentary (1).

32. [91] Dentition on coronoid: broad marginal "tooth field" $(0)$ : narrow marginal tooth row (1); single tooth row (2).

33. [98] Foramina on external surface of lower jaw: absent (0): present (1).

34. [109] Median gular: present (0): absent (1).

35. [113] Palatal opening surrounded by premaxilla. maxilla. dermopalatine. and vomer: absent (0); present (1).

36. [120] Articulation of parasphenoid: parasphenoid not sutured to vomer (0): parasphenoid sutured to vomer (1).

37. [122] Buccohypophysial foramen of parasphenoid: single (0): double (1).

38. [124] Parasphenoid: protruding forward in ethmoid region of endocranium (0); behind ethmoid region (1).

39. [131] Dorsal endoskeletal articulation between otico-occipital and ethmosphenoid blocks of braincase: absent (0); present (1).

40. [132] Ventral endoskeletal articulation between otico-occipital and ethmosphenoid blocks of braincase: absent (0); present (1).

41. [133] Orientation of intracranial joint or fissure: vertical or anteroventrally slanting (0): posteroventrally slanting (1).

42. [134] Position of intracranial joint or fissure relative to cranial nerves; joint through profundus foramen $(0)$; joint through trigeminal foramen (1).

43. [135] Processus descendens of sphenoid: absent (0): present (1).

44. [136] Fossa autopalatina: absent (0): present (1).

45. [142] Vomeral area with grooves and raised areas: absent $(0)$ : present (1).

46. [143] Fenestra ventralis: absent (0): large. medially situated (1): small. laterally situated (2).

47. [144] Large median opening and several small dorsolateral openings in postnasal wall: absent (0); present (1).

48. [148] Postorbital process on braincase: present $(0)$ : absent (1).

49. [152] Basicranial fenestra with arcual plates: absent $(0)$ : present (1).

50. [154] Otico-sphenoid bridge: present (0): absent (1).

51. [156] Posttemporal fossae: absent (0): present (1).

52. [161] Dorsal cleithrum (AL of the Placodermi). ventral cleithrum (AVL of the Placodermi) and pectoral spine (SP of the Placodermi): not fused (0), fused (1).

53. [170] Interclavicle: absent (0): present (1).

54. [174] Proximal articular surface of humerus: concave (0): flat (1): convex (1)

55. [186] Basal plates in dorsal fin supports: absent $(0)$; present $(1)$.

56. [198] Scales: rhombic (0): rounded (1).

57. [203] Cosmine: absent $(0)$ : present (1).

58. [207] Pore cluster: absent (0): present (1).

59. [208] Rostral tubuli: absent (0): present (1).

60. [214] Dendrodont plicidentine: absent (0): present (1).

61. [215] Polyplocodont plicidentine: absent (0): present simple (1). 


\section{Appendix 2}

Data matrix (based on descriptions of Gross 1942, Jarvik 1972, 1980, Vorobyeva 1980, Cloutier \& Schultze 1996, and on characters of Zhu \& Schultze in press)

\begin{tabular}{|c|c|c|c|c|c|c|}
\hline & $1-5$ & $6-10$ & $11-15$ & $16-20$ & $21-25$ & $26-30$ \\
\hline $\begin{array}{l}\text { 1. †Nasogaluakus } \\
\text { 2. † Glyptolepis } \\
\text { 3. †Holoptychius } \\
\text { 4. †Laccognathus } \\
\text { 5. †Porolepis } \\
\text { 6. †Powichthys } \\
\text { 7. †Quebecius } \\
\text { 8. †Youngolepis } \\
\text { 9. † Parolepis }\end{array}$ & $\begin{array}{lllll}0 & ? & 0 & 1 & 1 \\
0 & 1 & 0 & 0 & 1 \\
0 & 1 & 2 & 0 & 1 \\
0 & 0 & 0 & 0 & 1 \\
0 & 1 & 0 & 1 & 1 \\
0 & 1 & 2 & 1 & 0 \\
1 & 0 & 1 & 0 & 1 \\
? & ? & ? & 1 & 1 \\
0 & 1 & 1 & 1 & 0\end{array}$ & $\begin{array}{lllll}0 & 1 & 1 & 1 & 1 \\
1 & 1 & 1 & 1 & 1 \\
1 & 1 & 1 & 1 & 1 \\
1 & 1 & 1 & 1 & 1 \\
0 & 1 & 1 & 1 & 1 \\
0 & 0 & 0 & 0 & 0 \\
1 & 1 & 1 & 1 & 1 \\
? & 0 & 0 & 0 & 0 \\
? & 0 & 0 & 0 & 1\end{array}$ & $\begin{array}{ccccc}? & 0 & ? & ? & 0 \\
0 & 0 & 0 & 0 & 0 \\
0 & 0 & 0 & 0 & 0 \\
? & 1 & ? & ? & ? \\
0 & 0 & 0 & 0 & 0 \\
1 & 0 & 0 & 0 / 1 & 0 \\
? & 0 & 0 & 2 & 0 \\
1 & 1 & 1 & ? & 1 \\
0 & 0 & 0 & 0 & 1\end{array}$ & $\begin{array}{lllll}? & 1 & 1 & 1 & 1 \\
0 & 1 & 1 & 1 & 1 \\
0 & 1 & 1 & 1 & 1 \\
? & ? & ? & ? & ? \\
0 & 1 & 1 & 1 & 0 \\
1 & 0 & 2 & 1 & 0 \\
0 & 0 & 1 & 1 & 1 \\
1 & 0 & 1 & 0 & 0 \\
0 & 0 & 0 & 0 & 0\end{array}$ & $\begin{array}{lllll}? & 0 & ? & 0 & 1 \\
1 & 0 & 1 & 0 & 1 \\
1 & 0 & 1 & 0 & 1 \\
1 & 0 & 1 & 0 & 1 \\
1 & 1 & 1 & 0 & 1 \\
1 & 1 & ? & 0 & 1 \\
1 & 0 & 1 & 0 & 1 \\
0 & 0 & 0 & 1 & 0 \\
0 & ? & 0 & ? & 0\end{array}$ & $\begin{array}{lllll}? & ? & ? & ? & ? \\
1 & 0 & 0 & 0 & 1 \\
1 & 0 & 0 & 0 & 1 \\
1 & 0 & 0 & 0 & 1 \\
1 & 0 & 0 & 0 & 1 \\
1 & ? & ? & ? & 0 \\
1 & 0 & 0 & 1 & 1 \\
0 & 1 & 1 & 1 & 0 \\
0 & 1 & 0 & 1 & 0\end{array}$ \\
\hline & $31-35$ & $36-40$ & $41-45$ & $46-50$ & $51-55$ & $56-61$ \\
\hline $\begin{array}{l}\text { 1. } † \text { Nasogaluakus } \\
\text { 2. } † \text { Glypolepis } \\
\text { 3. Holoptychius } \\
\text { 4. †Laccognathus } \\
\text { 5. †Porolepis } \\
\text { 6. †Powichthys } \\
\text { 7. † Quebecius } \\
\text { 8. †Youngolepis } \\
\text { 9. †Parolepis }\end{array}$ & $\begin{array}{lllll}? & ? & ? & ? & ? \\
1 & 2 & 0 & 1 & 1 \\
1 & 2 & 1 & 1 & 1 \\
? & 2 & 1 & 1 & ? \\
0 & 2 & 0 & 0 & ? \\
0 & 0 & 1 & 0 & ? \\
? & ? & 0 & 1 & ? \\
0 & 0 & 1 & 0 & 0 \\
1 & 1 & 1 & 0 & 0\end{array}$ & $\begin{array}{lllll}? & ? & ? & ? & ? \\
0 & 1 & 1 & 1 & 1 \\
0 & 1 & 1 & 1 & 1 \\
? & ? & ? & ? & ? \\
0 & 1 & 1 & 1 & 1 \\
? & 0 & 1 & 1 & 1 \\
? & ? & ? & ? & ? \\
1 & 0 & 0 & 0 & 0 \\
0 & 0 & 1 & 1 & 1\end{array}$ & $\begin{array}{lllll}? & ? & ? & ? & ? \\
1 & 0 & 0 & 1 & 0 \\
1 & 0 & 0 & 1 & 0 \\
? & ? & ? & ? & ? \\
1 & 0 & 0 & 1 & 0 \\
0 & 1 & 1 & 0 & 0 \\
? & ? & ? & ? & ? \\
0 & 1 & 1 & 0 & 1 \\
0 & 0 & 1 & 1 & 1\end{array}$ & $\begin{array}{lllll}? & ? & ? & ? & ? \\
2 & 1 & 1 & 1 & 1 \\
2 & 1 & ? & 1 & 1 \\
? & ? & ? & ? & ? \\
2 & 1 & 1 & 1 & 1 \\
1 & 1 & 0 & 1 & 0 \\
? & ? & ? & ? & ? \\
1 & 0 & 0 & 0 & 0 \\
0 & 0 & ? & ? & ?\end{array}$ & $\begin{array}{ccccc}? & ? & ? & ? & ? \\
1 & 1 & 1 & 0 & 1 \\
? & 0 / 1 & 0 & ? & ? \\
? & 1 & 0 & ? & ? \\
? & 1 & ? & ? & ? \\
0 & 1 & ? & ? & ? \\
? & 1 & ? & ? & 0 \\
0 & 1 & ? & 1 & ? \\
0 & 0 & 1 & ? & ?\end{array}$ & $\begin{array}{cccccc}? & 0 & ? & ? & ? & ? \\
1 & 0 & ? & 0 & 1 & 0 \\
1 & 0 & ? & 0 & 1 & 0 \\
1 & 0 & 0 & 0 & 1 & 0 \\
0 & 1 & 0 & ? & 1 & 0 \\
0 & 1 & 1 & 1 & 0 & 1 \\
1 & 0 & 0 & ? & ? & ? \\
0 & 1 & 1 & 1 & 0 & 1 \\
? & 1 & ? & ? & 0 & 1\end{array}$ \\
\hline
\end{tabular}

